\title{
Distribution and Adsorption Characteristics of Phosphorus at A Headwater Wetland in Ichikawa City, Chiba Prefecture, Japan
}

\author{
Jingqiu Piao ${ }^{1}$, Changyuan Tang ${ }^{1}$, Toma Matsumaru ${ }^{1}$, Zhiwei Han $^{2}$, Hiroki Sakaguchi ${ }^{1} \&$ Shunichi Satake ${ }^{1}$ \\ ${ }^{1}$ Graduate School of Horticulture, Chiba University, Matsudo, Japan \\ ${ }^{2}$ College of Resources and Environmental Engineering, Guizhou University, Guiyang, China \\ Correspondence: Changyuan Tang, Graduate School of Horticulture, Chiba University, 648 Matsudo, \\ Matsudo-shi, Japan. Tel: 81-47-308-1714. E-mail: tangchangyuan@gmail.com
}

Received: October 22, 2015 Accepted: November 7, 2015 Online Published: February 15, 2016

doi:10.5539/ep.v5n1p31

URL: http://dx.doi.org/10.5539/ep.v5n1p31

\begin{abstract}
The distribution and adsorption characteristics of phosphorus were investigated in a typical headwater wetland in Ichikawa City, Chiba Prefecture, Japan. Total dissolved phosphorus (TDP) was the main phosphorus fraction in the waters, ranging from limit of quantification $(0.002 \mathrm{mg} / \mathrm{L})$ to $0.059 \mathrm{mg} / \mathrm{L}$ in spring water, from limit of quantification to $0.128 \mathrm{mg} / \mathrm{L}$ in groundwater and from 0.012 to $0.048 \mathrm{mg} / \mathrm{L}$ in river water. TDP in $33 \%$ water samples were higher than the environmental quality standard for eutrophication $(0.020 \mathrm{mg} / \mathrm{L})$. Next, phosphorus adsorption experiment was conducted to study phosphorus distribution in the aquifer where the equilibrium phosphorus concentration $\left(\mathrm{C}_{\mathrm{EPC}}\right)$ is the key to access the phosphorus in the waters. In addition, the amount of TDP releasing from the wetland through river was $20.9 \mathrm{~g} /$ day.
\end{abstract}

Keywords: phosphorus, adsorption characteristic, headwater wetland, groundwater

\section{Introduction}

Phosphorus is a major nutrient for aquatic ecology, and its excess supply can lead to eutrophication which from agricultural fields to surface and groundwater is one of the most serious environmental problems throughout the world (Salvia-Castellví et al., 2005; Diaz et al., 2003). In natural systems, phosphorus is mainly cycled through a plant-soil dynamic. However in agricultural systems, phosphorus is replenished with either mineral fertilizer or manure. Soils may be over applied with respect to phosphorus because many management programs are tied to nitrogen control or crop needs and phosphorus management is not always considered (Sharpley, 2003). The continued application of fertilizers and manures in many areas has resulted in the rise of soil phosphorus content above those required for optimum plant growth, which increase the potential for phosphorus loss (McDowell \& Sharpley, 2001a).

There is a tendency that total phosphorus (TP) in rivers in the central area of the US increases with the substantially increased application of fertilizer (Sprague \& Lorenz, 2009). These studies point out that content of phosphorus in aerated soil exceeds the capacity of adsorbing phosphorus due to the extreme agricultural activities and excessive application of phosphatic fertilizer in the above basins, accordingly the surplus phosphorus enters groundwater. In recent years, the presence of groundwater with high concentration phosphorus has been detected and has gradually become evident. The excessive inflow of phosphorus resulting in the eutrophication development of the drainage basin, especially the outflow of phosphorus from arable land, has attracted extraordinary attention (Salvia-Castellví et al., 2005; Board, 2000; Diaz et al., 2003; Sharpley, 2003; Sharpley\& Syers, 1979; Burwell et al., 1977; Baker et al., 1975). As shown in table 1, maximum concentrations of TP are obviously up to $0.050 \sim 1.759 \mathrm{mg} / \mathrm{L}$ in Northern Ireland, England, Wales, wetland basin at the south of Florida, Bysjiin Lake basin of Sweden and Nanjing and Taihu Lake basin of China. Especially at Bysjiin Lake basin of Sweden and Taihu Lake basin of China, the lowest values of TP concentrations detected are respectively as high as $0.117 \mathrm{mg} / \mathrm{L}$ and $0.158 \mathrm{mg} / \mathrm{L}$ (Table 1) (Chen et al., 2010; Holman et al., 2008; Price et al., 2006; Lu et al., 2001; Vanek, 1993). Therefore, the contribution of phosphorus from agricultural land transported by the groundwater flow should be a strong potential to significantly influence the surface aquatic ecosystem. 
Table 1. Average, maximum and minimum concentrations of phosphorus in the groundwater of the world

\begin{tabular}{|c|c|c|c|c|c|c|c|c|c|c|}
\hline Country & $\begin{array}{l}\text { Climatic } \\
\text { zones }\end{array}$ & Land use & $\begin{array}{c}\text { Average } \\
\text { annual } \\
\text { precipitation } \\
(\mathrm{mm} / \mathrm{Y})\end{array}$ & $\begin{array}{l}\text { Time } \\
\text { period }\end{array}$ & $\begin{array}{c}\text { Depth of } \\
\text { Groundwater } \\
\text { (m) }\end{array}$ & $\begin{array}{l}\text { Number } \\
\text { of } \\
\text { samples }\end{array}$ & $\begin{array}{c}\text { Average of } \\
\text { P } \\
\text { Conc. } \\
(\mathrm{mg} / \mathrm{L})\end{array}$ & $\begin{array}{l}\text { P Conc. } \\
\text { Max } \\
(\mathrm{mg} / \mathrm{L})\end{array}$ & $\begin{array}{l}\text { P Conc. } \\
\text { Min } \\
(\mathrm{mg} / \mathrm{L})\end{array}$ & Reference \\
\hline Northern Ireland & $\begin{array}{l}\text { Temperate } \\
\text { zone marine } \\
\text { climate }\end{array}$ & national-scale & n.d. & 2000-2006 & n.d. & 513 & n.d. & 0.100 & 0.028 & Holman et al., 2008 \\
\hline England and Wales & $\begin{array}{l}\text { Temperate } \\
\text { zone marine } \\
\text { climate }\end{array}$ & national-scale & n.d. & $1974-2006$ & n.d. & 38998 & n.d. & 0.050 & 0.001 & Holman et al., 2008 \\
\hline The USA (Florida) & $\begin{array}{c}\text { Subtropical } \\
\text { humid climate }\end{array}$ & Everglades & 1400 & 2003 & $0.6-19.8$ & 14 & 0.033 & 0.070 & 0.004 & Price et al., 2006 \\
\hline Sweden(Scania) & $\begin{array}{l}\text { Mediterranea } \\
\text { n climate }\end{array}$ & $\begin{array}{c}\text { Woods, } \\
\text { village, } \\
\text { fields,meadows }\end{array}$ & 1010 & 1991 & $0.25-6.0$ & 9 & 0.673 & 1.181 & 0.117 & Vanek, 1993 \\
\hline China (Nanjing) & $\begin{array}{l}\text { Subtropical } \\
\text { monsoon } \\
\text { climate }\end{array}$ & City & 1107 & 1999 & $0.3-1.5$ & 8 & 0.456 & 1.759 & 0.010 & Lu et al., 2001 \\
\hline China (Taihu) & $\begin{array}{l}\text { Subtropical } \\
\text { monsoon } \\
\text { climate }\end{array}$ & Fameland & 1200 & 2006-2007 & 2.0 & 3 & 0.188 & 0.225 & 0.158 & Chen et al., 2010 \\
\hline
\end{tabular}

n.d.: no data.

It is known that phosphorus tends to be adsorbed by $\mathrm{Fe} / \mathrm{Al}$ hydroxides, clay minerals and calcium carbonate (Zhang \& Huang, 2007; Arias et al., 2001; Parfitt, 1978; Hemwall, 1957; Cole et al., 1953). It has been recognized that excessive fertilizer will result in the adsorption of phosphoric acid before it reaches groundwater by previous research. It has been assumed that phosphorus transport to groundwater is negligible due to sorption and therefore earlier studies on phosphorus transport have been focused solely on surface water pathways. Therefore, scientists has paid attention to the four factors (grain size, ORP, $\mathrm{pH}$ and organic substance) affecting the adsorption of phosphorus in soil and the outflow of phosphorus from arable land to river during precipitation (Hiroyuki et al., 1998; Kunimatsu et al., 1994; Tadashi et al., 1993; Jiang et al., 2008; Wang et al., 2005; Andrieux-Loyer \& Aminot, 2001; Sharpley \& Syers, 1979; Burwell et al., 1977; Baker et al., 1975; Vollenweider, 1968). The amount of phosphorus released from soil to water is also dependent upon the soil phosphorus quantity-intensity relationship and the kinetics of phosphorus desorption. Many methods have been used to examine the kinetics of phosphorus desorption (Elkhatib \& Hern, 1988; Sharpley et al., 1981; Lookman et al., 1995)

At the landscape level, streams and wetlands form a critical interface between uplands and adjacent water bodies, as all of these ecosystems are hydrologically linked. Water and phosphorus are transported from uplands either by subsurface or surface flow (Reddy et al., 1999). Many advocates of decreasing phosphorus loss from soil to water have focused attention on management practices that minimize the potential for $\mathrm{P}$ transfer by surface flow. One such strategy is to retire land by taking it out of agricultural production that had previously been intensively managed or to impose conservation measures that reduce erosion, such as converting cultivated fields to grass (Lowrance et al., 1997). However, while such strategies may successfully decrease the contribution of phosphorus to surface waters via overland flow (Heathwaite et al., 1998). Phosphorus in subsurface pathways may contribute eutrophication of surface waters (McDowell \& Sharpley, 2001b). Therefore, the transport of phosphorus in subsurface pathways should be paid attention in the valley wetland surrounded by agricultural upland especially. 
In Japan, large amounts of phosphatic fertilizer had been applicated recent decades due to the shortage of effective phosphorus, where the consumption of chemical phosphoric fertilizer in unit cultivated land area has reached the world highest value (Nishio, 2005). The agricultural area of Chiba Prefecture, Japan, in 2011 was 128100 ha, ranking 8th among all prefectures of Japan. Since 1954, upland in Chiba Prefecture has been mostly changed to farmland where large quantities of pear trees had been grown, making it one of the few origins of pears in Japan. It has been found that phosphorus accumulation in soil due to application of fertilizer (Piao et al., 2013; Bennett et al., 2001). Groundwater-fed wetlands are main discharge areas of upland, the outflow of phosphorus flowed with groundwater discharged to rivers, lakes and swamps can be obstructed by adsorption, sedimentation and uptake of aquatic plants, making the water purified naturally (Groffman et al., 2006; Verhoeven et al., 2006; Sakadevan \& Bavor, 1998). However, in recent years, it has been pointed out that the outflow of phosphorus from groundwater and spring water to rivers, lakes and swamps may influence the inland aquatic ecosystem (Kang et al., 2005). But there is little study concerning mechanism of the transport of phosphorus in aquifer and its outflow to rivers.

Therefore, a representative wetland which is severely affected by agricultural activities has been selected as the study area, the rivers recharged by groundwater, spring water in the wetland is finally flowed into Tokyo Bay. If the river water is excess nutrient, these nutrients especially phosphorus as the limiting nutrient factor for eutrophication may result in coastal eutrophication. This study investigated groundwater, spring water and river water in the wetland catchment based on the eutrophication environmental standard of TP $(0.020 \mathrm{mg} / \mathrm{L})$ Japanese environmental standard in the coastal sea. The primary goal of the study was to 1) investigate the distribution of phosphorus in groundwater, spring water, river water and soil, 2) illustrate the mechanism of phosphorus transport along the groundwater flow paths and 3) estimate the load of phosphorus outflow from the wetland catchment.

\section{Description of Study Area}

The representative wetland catchment in Omachi, Chiba Prefecture mainly consists of upland, slope and wetland (Fig. 1). The elevation of the wetland is $12 \sim 13 \mathrm{~m}$ lower than the surrounding upland which is in quaternary strata. The upland consists of surface soil, Kanto loam layer, clay layer and Narita sand layer from top to bottom. In wetland, sequence of strata is surface soil, Kanto loam layer (sand mixture), clay sand layer and Narita sand layer (Fig. 2) from top to bottom.
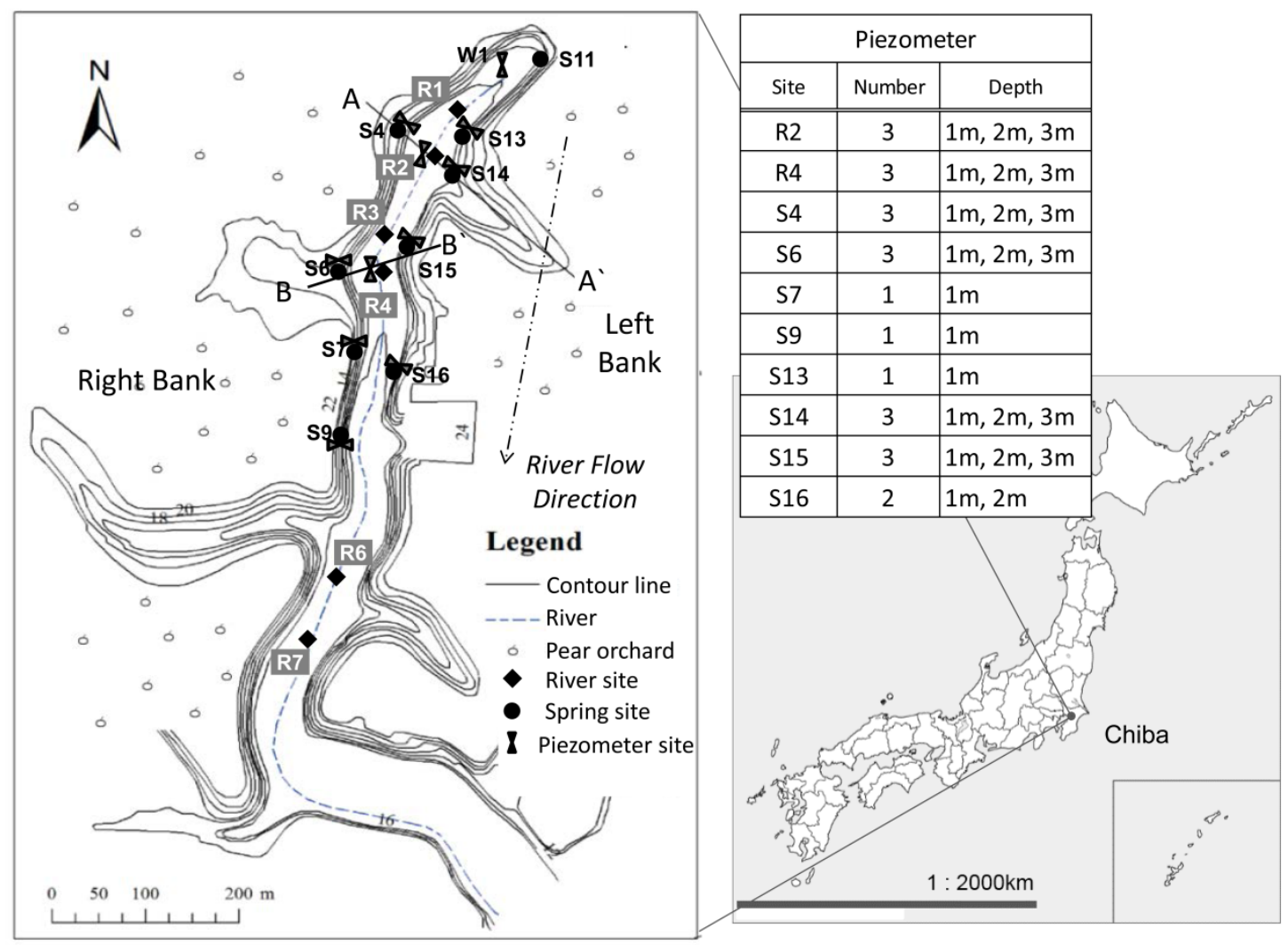

Figure 1. Map of the study area and sampling site 


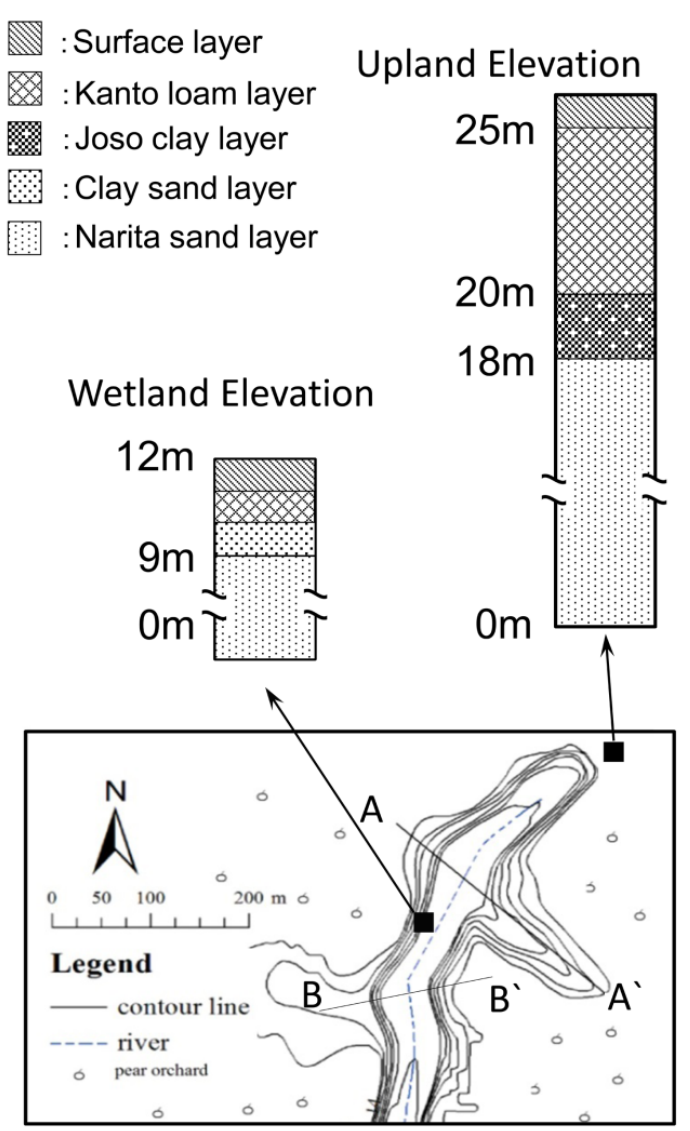

Figure 2. Stratigraphic columns in the study area

As recharge area of the wetland, the surrounding upland once had a wide coniferous forest which became pear trees later. At the slope adjacent to the upland, there are coniferous trees like cyptmeria, evergreen broad-leaved trees like bur oak, deciduous broad-leaved trees like konara oak and bamboos. At the bottom of the slope adjacent to the wetland, there is much spring water, which is the discharge of upland groundwater. In the wetland, vegetations such as reed, goldenrod, paddy field leaf mustard and alder are distributed. The rivers in the wetland are recharged by spring water, and groundwater and groundwater in the well at the upland with the depth of $40 \mathrm{~m}$ is the source of the waters in the wetland. Rivers in wetland flow into Okashiwa River and eventually to Tokyo Bay.

In the study area, the climate is comparatively warm, belonging to the pacific shore climate with substantial precipitation in summer. According to data of the observation point (Funabashi) of nearby meteorological agency AMeDAS (Automated Meteorological Data Acquisition), from 1981 to 2010, the annual mean precipitation is $1362 \mathrm{~mm}$, and the annual mean temperature is $14.7^{\circ} \mathrm{C}$ (data source: Japanese Meteorological Agency, Funabashi Meteorological Station).

\section{Methods}

\subsection{Sampling}

In order to investigate groundwater quality and flow characteristic, 23 piezometers (PVC, $950 \mathrm{~mm}$ ) were installed at three depth of $1 \mathrm{~m}, 2 \mathrm{~m}$ and $3 \mathrm{~m}$ at 11 sites in the wetland according to the strata distribution (Fig 1).

From June 2011 to May 2013, the flow of the river in different cross sections, the discharge of W1 (well) and hydraulic heads of piezometers in wetland were measured. In June 2012, water samples including river water, groundwater and spring water of 39 sites were collected. Before the groundwater sampling, initially, whole water in the piezometer was withdrawn out to let fresh groundwater flow in, then the fresh groundwater was collected. The $\mathrm{pH}$, electrical conductivity (EC) and oxidation-reduction potential (ORP) of the water samples were measured with portable meters (HORIBA D-52) at sampling site. Water samples for TP analysis were initially filtrated through a $0.45 \mu \mathrm{m}$ membrane filter and then collected in pre-clean $100 \mathrm{ml}$ plastic bottles, unfiltered water samples for TDP analysis were collected in pre-clean $100 \mathrm{ml}$ plastic bottles. All of the water samples were 
stored at $4^{\circ} \mathrm{C}$ until analysis.

For the investigation of the content of phosphorus in soil and sediment, surface soils $(0 \sim 20 \mathrm{~cm})$ at the springs and sediments from river bed and piezometers of each sampling site were collected in aluminum foil. The samples were taken to the laboratory in sealed plastic bags and air dried. Then air-dried samples were ground and sieved with a standard $2 \mathrm{~mm}$ sieve and collected in glass bottles for further experimental studies.

\subsection{Analytical Techniques}

All water samples were analyzed in the Laboratory of Graduate School of Horticulture, Chiba University. Blanks and appropriate certified standard reference materials were analyzed as unknowns.

TP and TDP in the water was determined using the molybdenum-blue method (Baehr \& McManus, 2003). Values of total particulate phosphorus (TPP) in water sample were derived as TP-TDP.

The grain size distribution of sediment and soil samples was analyzed using sedimentation method with grain size below $0.05 \mathrm{~mm}$ (Association, 2000) Loss on ignition (LOI) of soil and sediment measurement were based on weight losses after drying and combustion at $550^{\circ} \mathrm{C}$. (Santisteban et al., 2004; Kaiserli et al., 2002).

For the measuring of soil total phosphorus (STP), the phosphorus was extracted from soil samples using $\mathrm{NaOH}$ solution firstly, then determined using the molybdenum-blue method (Wang et al., 2009).

In the phosphorus adsorption experiments, $0.3 \mathrm{~g}\left(\mathrm{M}_{0}\right)$ soil sample was placed in acid-washed centrifugal tube (50 $\mathrm{ml}$ ) and $30 \mathrm{ml}\left(\mathrm{V}_{0}\right)$, then the phosphoric acid standard solution (anhydrous $\left.\mathrm{KH}_{2} \mathrm{PO}_{4}\right)$ with concentration $\left(\mathrm{V}_{0}\right)$ of 0 , $0.05,0.1,0.2,0.4,0.7$ and $1.0 \mathrm{mg} / \mathrm{L}$ was added in centrifugal tube initially. Secondly the centrifugal tubes were vibrated for 48 hours using vibrator (Way, 2012). Then, TP concentration (equilibrium concentration, $\mathrm{C}_{\mathrm{eq}}$ ) of supernatant liquid in centrifugal tube was determined using the molybdenum-blue method (Baehr and McManus, 2003). In addition, three adsorption experiments were carried out at each sampling site and the average value was used. However, because the groundwater at the study area contained oxygen, the condition of DO concentration in this experiment was not set specifically. The TP concentration of supernatant liquid in this experiment is equilibrium concentration $\left(\mathrm{C}_{\mathrm{eq}}\right)$. The amount of phosphorus adsorbed under the equilibrium condition $(\mathrm{Q}: \mathrm{mg} / \mathrm{kg}$ ) can be calculated by the following equation:

$$
\mathrm{Q}=\left(\mathrm{C}_{0}-\mathrm{C}_{\mathrm{eq}}\right) \times \mathrm{V}_{0} / \mathrm{M}_{0} \times 10^{6}
$$

Where, $\mathrm{C}_{0}$ is the initial concentration of solution $(\mathrm{mg} / \mathrm{L})$

$\mathrm{C}_{\mathrm{eq}}$ is the concentration of solution under equilibrium condition $(\mathrm{mg} / \mathrm{L})$

$\mathrm{V}_{0}$ is volume of solution $(\mathrm{L})$

$\mathrm{M}_{0}$ is weight of soil sample ( $\mathrm{mg}$ )

Moreover, the river recharged by groundwater, spring water in the wetland is finally flowed into Tokyo Bay. If the river water is excess nutrient, these nutrients especially phosphorus as the limiting nutrient for eutrophication may result in coastal eutrophication. Therefore, this study investigated groundwater, spring water and river water in the wetland catchment based on the eutrophication environmental standard of TP $(0.020 \mathrm{mg} / \mathrm{L})$ Japanese environmental standard in the coastal sea.

\section{Results and Discussion}

\subsection{Characteristic of Groundwater Flow within the Wetland}

The disribution of hydraulic heads on two cross sections (A-A', B-B') in the wetland were investigated using piezometers (Fig. 3). Based on disribution of hydraulic heads, the direction of groundwater flow could be estimated on corss sections. The hydraulic head (m) was calculated using the following equation:

$$
\mathrm{h}=\mathrm{h}_{1}+\mathrm{h}_{2}-\mathrm{h}_{3}
$$

Where, $\mathrm{h}_{1}$ is elevation $(\mathrm{m})$

$\mathrm{h}_{2}$ is the elevation at the top of piezometer (m)

$\mathrm{h}_{3}$ is the distance from the top of piezometer to water surface in piezometer (m) 

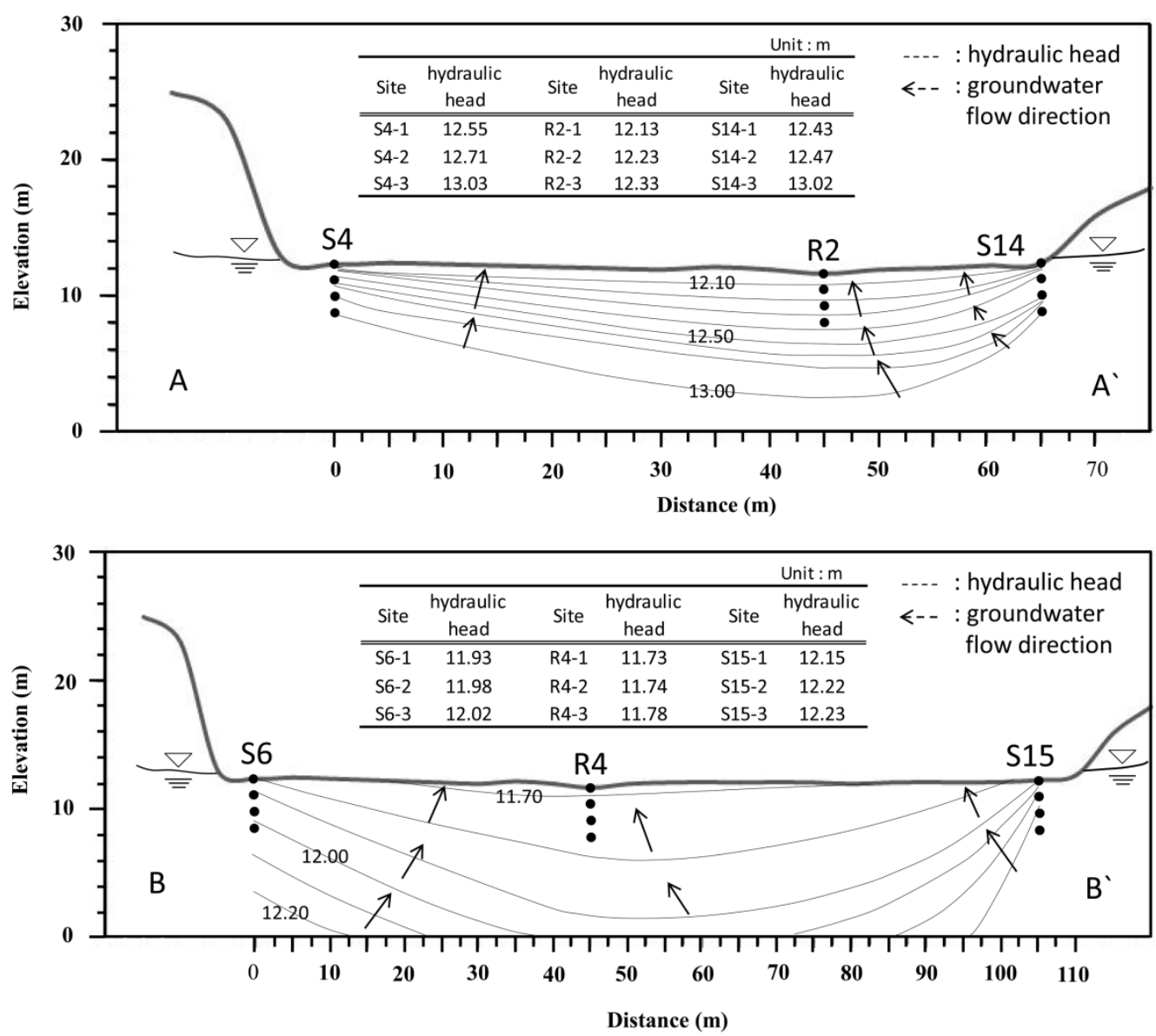

Figure 3. Schematic view of hydraulic head distribution in A-A' (a) and B-B' (b) cross sections

As shown in Fig. 3 (a, b), based on the distribution of hydraulic head on section A-A' and B-B', it is found that the hydraulic heads at R2 were lower than those at S4 and S14 in the same depth, the similar tendency was also found on the B-B' section. Moreover, hydraulic heads of groundwater at all sites increased from $1 \mathrm{~m}$ to $3 \mathrm{~m}$ depth. These characteristics indicated that groundwater was upward in the valley wetland. According to the landform of the valley catchment, groundwater should flow out as springs at the slope foot adjacent to the wetland, or seep directly at the wetland surface.

Furthermore, groundwater in $\mathrm{W} 1$ was pumped with the flow of $1.9 \mathrm{~L} / \mathrm{s}$ perennial and discharged into the river, and the flow of the river $(5.8 \sim 19.7 \mathrm{~L} / \mathrm{s})$ to was increasing from upstream to downstream. (Fig. 4). These evidences directly suggested that the wetland was maintained by groundwater or spring. 


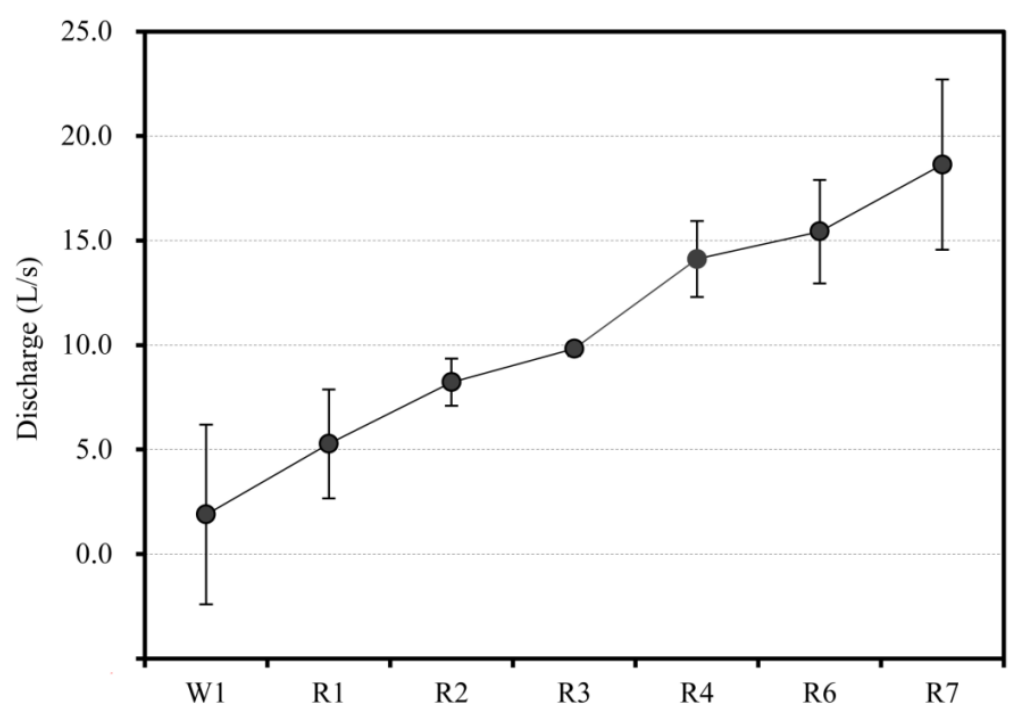

Figure 4. The river flow from upstream to downstream

\subsection{The Parameters of Waters in the Wetland}

The $\mathrm{pH}$ of the groundwater, spring water and river water ranged from 6.2 to 8.3 . ORP of waters ranged from -150 to $328 \mathrm{mV}$; EC was $14.3 \mathrm{mS} / \mathrm{m}$ in $\mathrm{W} 1$ and ranged from 16.8 to $61.0 \mathrm{mS} / \mathrm{m}$ in groundwater. EC of river water varied from 15.7 to $40.6 \mathrm{mS} / \mathrm{m}$ (Table 2). EC of spring water was between 12.2 and $78.7 \mathrm{mS} / \mathrm{m}$, and which at right side was slightly larger than that of left side in the wetland. The EC of waters at the slope foot adjacent to the wetland was higher than that of groundwater near the river. 
Table 2. Basic parameters, TP, TDP and TPP concentrations of waters and GS, LOI and STP contents of soils in the wetland catchment

\begin{tabular}{|c|c|c|c|c|c|c|c|c|c|c|}
\hline \multirow[b]{2}{*}{ ID } & \multirow[b]{2}{*}{ Depth (m) } & \multicolumn{6}{|c|}{ water } & \multicolumn{3}{|c|}{ soil } \\
\hline & & $\begin{array}{c}\mathrm{EC} \\
(\mathrm{mS} / \mathrm{m})\end{array}$ & $\mathrm{pH}$ & $\begin{array}{l}\text { ORP } \\
(\mathrm{mV})\end{array}$ & $\begin{array}{c}\text { TP } \\
(\mathrm{mg} / \mathrm{L})\end{array}$ & $\begin{array}{c}\text { TDP } \\
(\mathrm{mg} / \mathrm{L})\end{array}$ & $\begin{array}{c}\text { TPP } \\
(\mathrm{mg} / \mathrm{L})\end{array}$ & $\begin{array}{c}\mathrm{GS} \\
<0.05 \mathrm{~mm} \\
(\%)\end{array}$ & $\begin{array}{l}\text { LOI } \\
(\%)\end{array}$ & $\begin{array}{c}\text { STP } \\
(\mathrm{mg} / \mathrm{kg})\end{array}$ \\
\hline W1 & 60 & 14.3 & 7.0 & 139 & 0.135 & 0.128 & 0.008 & n.d. & n.d. & n.d. \\
\hline $\mathrm{R} 1$ & Surface & 15.7 & 7.7 & 178 & 0.048 & 0.042 & 0.005 & 2 & 2.5 & 207 \\
\hline $\mathrm{R} 2$ & Surface & 27.3 & 7.7 & 189 & 0.049 & 0.048 & L.L.Q. & 8 & 2.0 & 188 \\
\hline R2-1 & 1 & 16.8 & 7.0 & -27 & 0.006 & L.L.Q. & 0.004 & 31 & 23.8 & 448 \\
\hline R2-2 & 2 & 22.1 & 7.5 & -150 & 0.090 & 0.072 & 0.019 & 29 & 36.1 & 268 \\
\hline R2-3 & 3 & 22.6 & 7.7 & 51 & 0.075 & 0.068 & 0.006 & n.d. & 29.7 & 209 \\
\hline $\mathrm{R} 3$ & Surface & 40.6 & 7.4 & 132 & 0.042 & 0.035 & 0.007 & n.d. & 2.7 & 225 \\
\hline $\mathrm{R} 4$ & Surface & 33.1 & 8.0 & 283 & 0.026 & 0.019 & 0.007 & 7 & 7.4 & 717 \\
\hline R4-1 & 1 & 25.5 & 7.0 & -36 & 0.003 & L.L.Q. & L.L.Q. & 47 & 44.6 & 512 \\
\hline R4-2 & 2 & 27.5 & 7.0 & -41 & 0.014 & 0.010 & 0.004 & 35 & 39.0 & 490 \\
\hline $\mathrm{R} 4-3$ & 3 & 30.7 & 7.2 & 146 & 0.008 & 0.006 & L.L.Q. & 31 & 32.9 & 342 \\
\hline R6 & Surface & 36.2 & 7.2 & 247 & 0.022 & 0.017 & 0.005 & n.d. & 5.4 & 671 \\
\hline R7 & Surface & 33.3 & 8.1 & 217 & 0.015 & 0.012 & 0.003 & n.d. & 4.6 & 505 \\
\hline $\mathrm{S} 4$ & Surface & 61.2 & 7.0 & 284 & 0.007 & 0.004 & 0.003 & 2 & 38.2 & 1805 \\
\hline S4-1 & 1 & 46.9 & 7.5 & 269 & 0.028 & 0.026 & L.L.Q. & 21 & 4.9 & 144 \\
\hline S4-2 & 2 & 44.9 & 7.5 & 269 & 0.024 & 0.018 & 0.006 & 22 & 3.6 & 157 \\
\hline S4-3 & 3 & 36.2 & 7.7 & 280 & 0.025 & 0.022 & 0.003 & 26 & 2.7 & 121 \\
\hline S6 & Surface & n.d. & n.d. & 328 & 0.024 & 0.009 & 0.015 & 2 & 17.7 & 1511 \\
\hline S6-1 & 1 & 30.8 & 7.6 & 280 & 0.004 & 0.003 & L.L.Q. & 48 & 5.4 & 202 \\
\hline S6-2 & 2 & 51.7 & 7.5 & 308 & 0.003 & 0.003 & L.L.Q. & 16 & 2.3 & 92 \\
\hline S6-3 & 3 & 55.6 & 6.9 & 308 & 0.004 & 0.004 & L.L.Q. & 21 & 2.7 & 140 \\
\hline S7 & Surface & 65.6 & 7.5 & 267 & 0.055 & 0.037 & 0.018 & n.d. & 8.7 & 316 \\
\hline S7-1 & 1 & 53.2 & 8.0 & 277 & 0.011 & 0.011 & L.L.Q. & n.d. & 2.1 & 122 \\
\hline S9 & Surface & 78.7 & 7.7 & 231 & 0.003 & L.L.Q. & L.L.Q. & n.d. & 3.5 & 207 \\
\hline S9-1 & 1 & 61.0 & 7.8 & 197 & 0.004 & 0.003 & L.L.Q. & n.d. & 1.4 & 133 \\
\hline $\mathrm{S} 11$ & Surface & 46.7 & 6.7 & 246 & 0.005 & 0.003 & L.L.Q. & n.d. & 1.7 & 165 \\
\hline $\mathrm{S} 13$ & Surface & 38.6 & 7.4 & 236 & 0.005 & 0.003 & L.L.Q. & n.d. & 4.8 & 239 \\
\hline S13-1 & 1 & 34.2 & 7.8 & 211 & 0.046 & 0.025 & 0.021 & n.d. & 1.6 & 114 \\
\hline $\mathrm{S} 14$ & Surface & 12.2 & 6.2 & 107 & L.L.Q. & L.L.Q. & L.L.Q. & 2 & 15.4 & 323 \\
\hline S14-1 & 1 & 40.2 & 6.7 & 126 & 0.013 & 0.007 & 0.006 & 19 & 8.4 & 620 \\
\hline $\mathrm{S} 14-2$ & 2 & 46.1 & 6.8 & 168 & 0.016 & 0.015 & L.L.Q. & 10 & 3.3 & 147 \\
\hline S14-3 & 3 & 35.9 & 7.0 & 164 & 0.019 & 0.018 & L.L.Q. & 29 & 3.1 & 125 \\
\hline S15 & Surface & n.d. & n.d. & n.d. & 0.028 & 0.010 & 0.018 & 2 & 6.6 & 140 \\
\hline S15-1 & 1 & 31.9 & 7.5 & 192 & 0.036 & 0.011 & 0.025 & 26 & 3.0 & 112 \\
\hline $\mathrm{S} 15-2$ & 2 & 48.7 & 7.5 & 313 & 0.009 & 0.007 & L.L.Q. & 18 & 2.5 & 126 \\
\hline S15-3 & 3 & 38.5 & 6.9 & 306 & 0.011 & 0.005 & 0.006 & 17 & 2.9 & 127 \\
\hline S16 & Surface & 31.5 & 8.0 & 187 & 0.094 & 0.059 & 0.035 & 2 & 4.1 & 209 \\
\hline S16-1 & 1 & 37.2 & 8.3 & 272 & 0.058 & 0.054 & 0.004 & 6 & 2.3 & 109 \\
\hline S16-2 & 2 & 42.3 & 8.0 & 235 & 0.055 & 0.054 & L.L.Q. & 17 & 2.8 & 144 \\
\hline Standard deviation & & 14.6 & 0.5 & 110.2 & 0.0 & 0.0 & 0.0 & 13.3 & 12.5 & 356.4 \\
\hline
\end{tabular}

L.L.Q.: Lower Limit of Quantification; n.d.: no data. 
ORP of groundwater near the river were lower than those of groundwater at two sides in the wetland. It was also obvious that ORP of groundwater trended decrease in the upward groundwater at all investigated sites, indicating that ORP of groundwater was decreasing along the groundwater flow direction. Furthermore, The $\mathrm{pH}$ and EC of groundwater were also trended decrease along the flow direction at most investigated sites, which was the same as the characteristics of $\mathrm{NO}_{3}{ }^{-}$and $\mathrm{SO}_{4}{ }^{2-}$ in groundwater of the wetland (Han et al., 2014). It could be concluded that the characteristics of $\mathrm{pH}, \mathrm{ORP}$ and $\mathrm{EC}$ of the groundwater were mainly affected by processes of reduction in the wetland, which was the biochemical purification.

\subsection{The Distribution of Phosphorus in Groundwater and Spring Water}

Wetlands provide multiple microenvironments that provide the necessary conditions for interconversions of various forms of phosphorus. Phosphorus entering stream from wetland is typically present in various forms. To trace the transport and transformations of phosphorus, forms of phosphorus in waters were classified as TP, TDP and TPP. The relative proportion of each form depends on soil, vegetation, and land use characteristics of the drainage basin (Reddy et al., 1999).

Concentrations of TP, TDP and TPP in groundwater at different depth and spring water were shown in Fig. 5. Concentrations of TP in groundwater ranges were $0.004 \sim 0.075 \mathrm{mg} / \mathrm{L}$ at depth of $3 \mathrm{~m}, 0.003 \sim 0.090 \mathrm{mg} / \mathrm{L}$ at depth of $2 \mathrm{~m}, 0.003 \sim 0.058 \mathrm{mg} / \mathrm{L}$ at depth of $1 \mathrm{~m}$. The TP concentrations in spring water varied between 0.003 and $0.094 \mathrm{mg} / \mathrm{L}$. The TP concentrations of 9 groundwater samples (R2-2m, R2-3m, S4-1m, S4-2m, S4-3m, S13-1m, S15-1m, S16-1m, S16-2m) and 4 spring water samples (S6, S7, S15, S16) exceeded the environmental standard $(0.020 \mathrm{mg} / \mathrm{L})$. Water samples that exceed the environmental standard $(0.020 \mathrm{mg} / \mathrm{L})$ was account for about $41 \%$.

Concentrations of TDP in groundwater ranges were $0.005 \sim 0.068 \mathrm{mg} / \mathrm{L}$ at depth of $3 \mathrm{~m}, 0.003 \sim 0.072 \mathrm{mg} / \mathrm{L}$ at depth of $2 \mathrm{~m}$, undetectable $0.054 \mathrm{mg} / \mathrm{L}$ at depth of $1 \mathrm{~m}$. Of the 23 groundwater samples, 7 samples (R2-2, R2-3, S4-1, S4-3, S13-1, S16-1, S16-2) exceed the environmental standard (0.020 mg/L). TDP concentrations of the spring water ranged from undetectable to $0.059 \mathrm{mg} / \mathrm{L}$, and 2 samples (S7 and S16) exceeded the environmental standard $(0.020 \mathrm{mg} / \mathrm{L})$. Groundwater at different depth was observed in the middle of the wetland maintained under aerobic-, nitrate-, and sulfate-reducing conditions, and methanogenic conditions from $3 \mathrm{~m}$ to $1 \mathrm{~m}$ depth, respectively (Han et al., 2014). Wetlands are also used to treat municipal wastewater due to the reduction function (Yan et al., 2012). Influenced by the redox condition and the presence of selected electron acceptors, the variability of TDP concentrations in groundwater at different depth at two sides were lower than that of groundwater in the middle of the wetland, where TDP concentrations in groundwater were decreased from $3 \mathrm{~m}$ to $1 \mathrm{~m}$ in depth. It was suggested that microorganisms can play a major role in phosphorus transformation. Microorganisms incorporate dissolved $\mathrm{P}$ into cellular constituent, that then become integral parts of the particulate matter. Through the formation of polyphosphate compounds, microorganisms are able to survive in alternating oxidation-reduction environments (Davelaar, 1993). Therefore, biological uptake can reasonably account for the majority of TDP transformations in groundwater. 


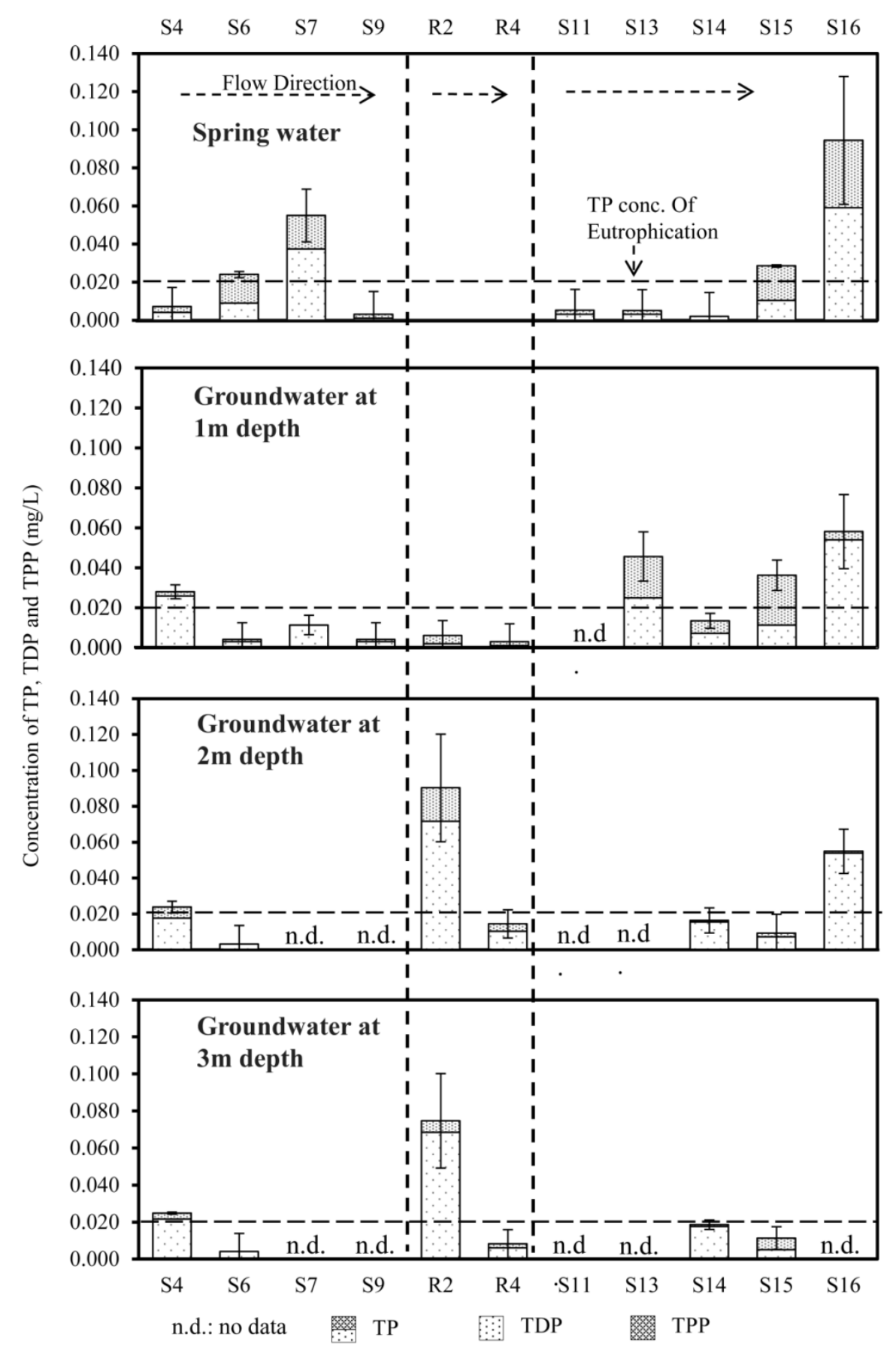

Figure 5. Concentrations of TP, TDP, TPP of spring water and groundwater

Concentrations of TPP in groundwater ranges were undetectable $0.006 \mathrm{mg} / \mathrm{L}$ at depth of $3 \mathrm{~m}$, undetectable $\sim 0.019 \mathrm{mg} / \mathrm{L}$ at depth of $2 \mathrm{~m}$, undetectable $0.025 \mathrm{mg} / \mathrm{L}$ at depth of $1 \mathrm{~m}$. TPP concentrations in spring water ranged from undetectable to $0.035 \mathrm{mg} / \mathrm{L}$ (Fig. 5). There was a good correct relation between TP and TDP of groundwater and spring water $\left(\mathrm{R}^{2}=0.91\right)$ (Fig. 6). TPP could be adsorbed easily in the strata, especially in the organic-riched wetland, resulted in poor mobility of TPP along with the groundwater flow direction. TPP concentrations were basically below the environmental standard $(0.020 \mathrm{mg} / \mathrm{L})$, and lower than TDP concentrations in groundwater and spring water. Therefore, the phosphorus flowed out with groundwater in the form of TDP basically. 


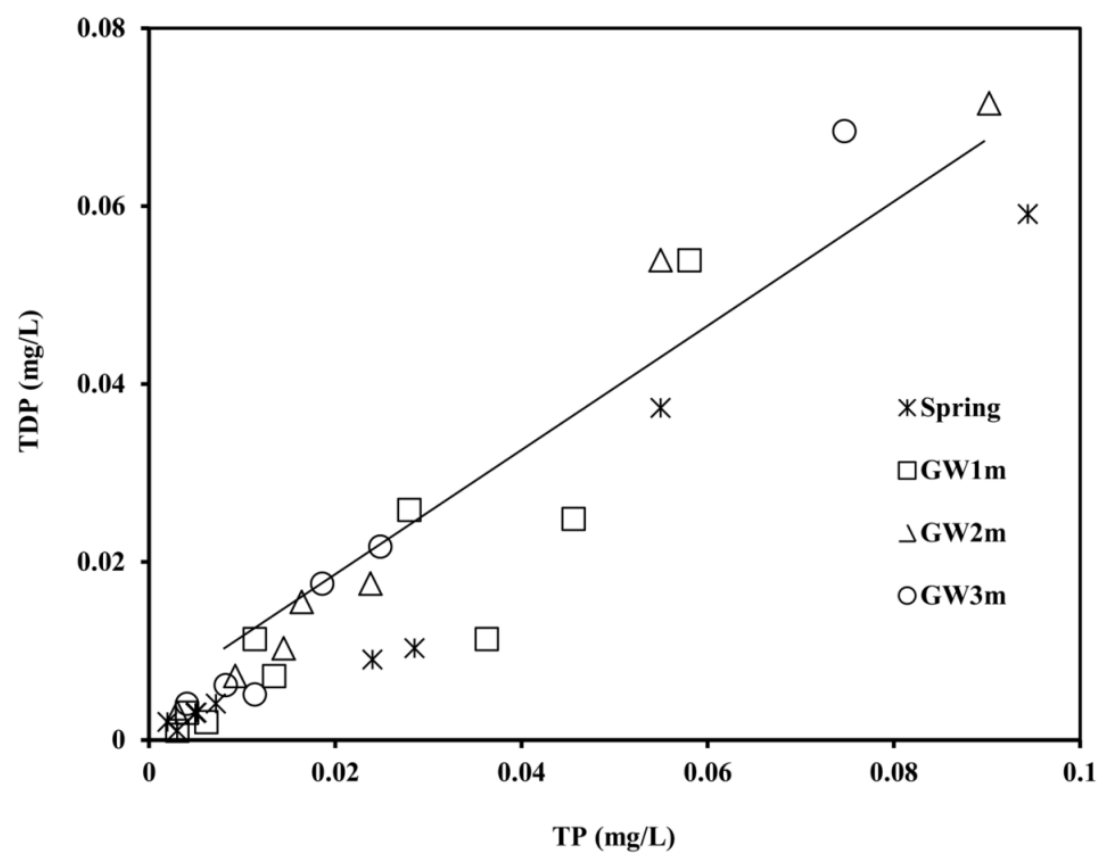

Figure 6. The correlation between TP and TDP of spring water and groundwater

\subsection{Characteristics of LOI, Grain Size Distribution and TP in Soil}

LOI of soil samples ranged from $1.4 \%$ to $44.6 \%$, and revealed that of surface soils were larger than those of river sediments and soils at depth of $1 \mathrm{~m}, 2 \mathrm{~m}$ and $3 \mathrm{~m}$. Moreover, LOI of soils at depth of $1 \mathrm{~m}, 2 \mathrm{~m}$ and $3 \mathrm{~m}$ varied from $23.8 \%$ to $44.6 \%$ at the slope, which were obviously larger than those of soils $(1.4 \sim 8.4 \%)$ at the same depth in the middle of the wetland. For the grain size distribution of soils, there proportion of silt particle (GS $<0.05 \mathrm{~mm})$ ranged from $11 \%$ to $88 \%$. The tendency that proportion of silt particle $(\mathrm{GS}<0.05 \mathrm{~mm})$ obviously rised with the depth from $1 \mathrm{~m}$ to $3 \mathrm{~m}$ (Table 2).

Soil total phosphorus (STP) ranged from 121 to $342 \mathrm{mg} / \mathrm{kg}$ at depth of $3 \mathrm{~m}$, from 92 to $490 \mathrm{mg} / \mathrm{kg}$ at depth of 2 $\mathrm{m}$, from 109 to $620 \mathrm{mg} / \mathrm{kg}$ at depth of $1 \mathrm{~m}$, from 140 to $1805 \mathrm{mg} / \mathrm{kg}$ at the surface of the wetland (Fig. 7). STP contents of soils at depth of $1 \mathrm{~m}, 2 \mathrm{~m}$ and $3 \mathrm{~m}$ in the center wetland were slightly larger than those at other sampling sites basically. Compared with STP contents at other sites $(92 \sim 620 \mathrm{mg} / \mathrm{kg})$, STP contents in surface soils at S4 $(1805 \mathrm{mg} / \mathrm{kg})$ and $\mathrm{S} 6(1511 \mathrm{mg} / \mathrm{kg})$ were extremely high due to the erosion of agriculture soils in the surrounding upland, which approach that of surface soils in the pear orchard (1723 mg/kg) (Piao et al., 2013). 


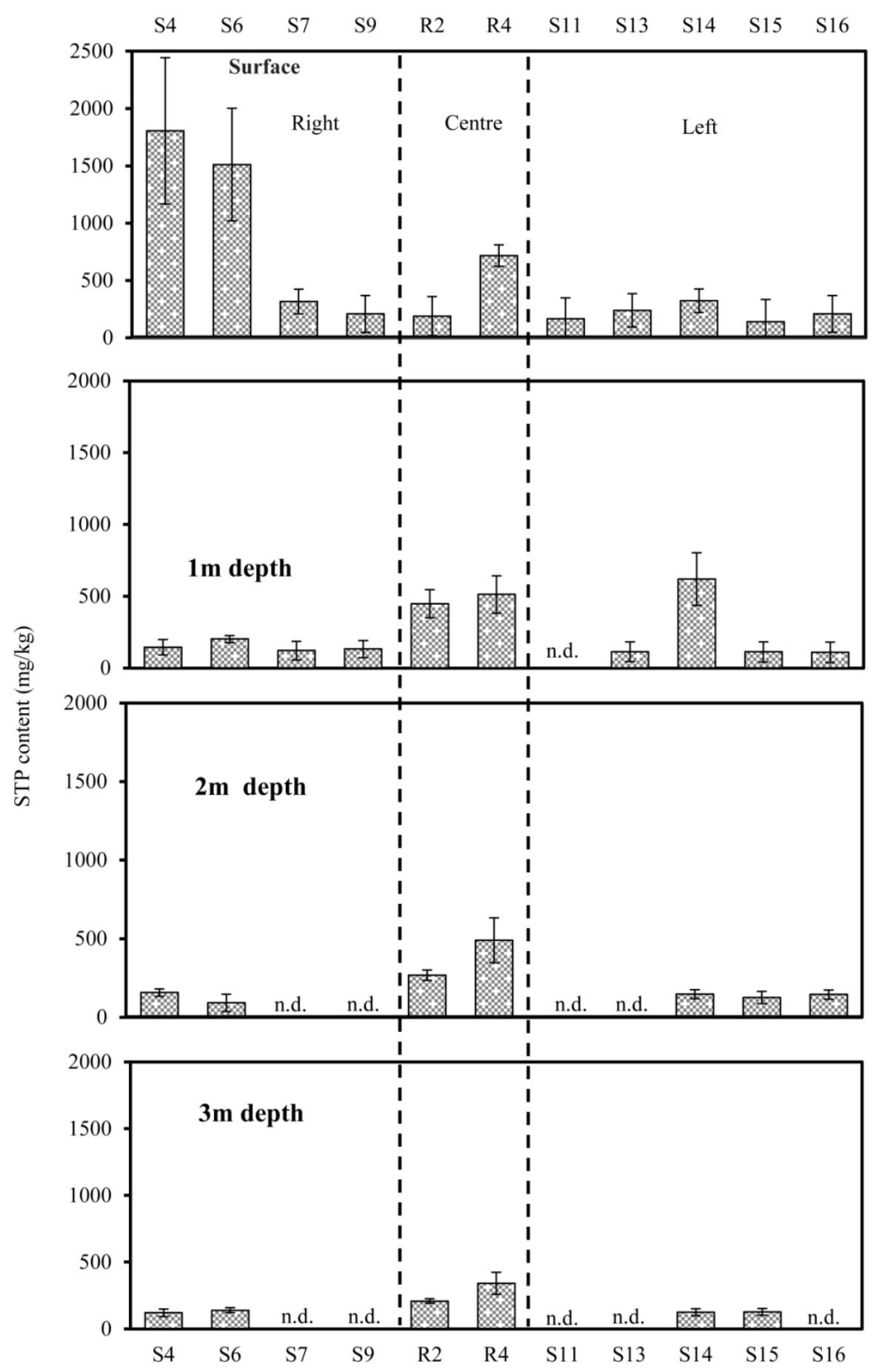

Figure 7. STP contents of soils at sampling sites

The STP content of soil is mainly affected by pH, ORP, grain size and LOI (Jiang et al., 2008; Wang et al., 2005; Andrieux-Loyer \& Aminot, 2001). A multiple regression equation for determining STP contents (target variable) was based on four factors (Table 3). However, only when the regression coefficient $\mathrm{F}<0.05$, the multiple regression equation is meaningful. And when $\mathrm{P}_{\alpha}<0.05$, the variable is meaningful. The multiple judgment coefficient $\mathrm{R}^{2}=0.70 . \mathrm{P}_{\alpha}$ of $\mathrm{pH}$ exceed 0.05 , and $\mathrm{P}_{\alpha}$ of ORP, LOI and grain size below silt $(\mathrm{GS}<0.05 \mathrm{~mm})$ was below 0.05 . Therefore, as the target variables, STP was not influenced by $\mathrm{pH}$, the influence factors should be grain size below silt $(\mathrm{GS}<0.05 \mathrm{~mm}), \mathrm{ORP}$ and LOI. The multiple regression equation was as follow:

$$
\mathrm{Y}(\mathrm{mg} / \mathrm{kg})=-139.72+1.74 \times \mathrm{X}_{1}-11.36 \times \mathrm{X}_{2}+28.26 \times \mathrm{X}_{3}
$$


Where, $\mathrm{Y}$ is phosphorus content in soil (STP) $(\mathrm{mg} / \mathrm{kg})$

$\mathrm{X}_{1}$ is $\mathrm{ORP}(\mathrm{mV})$

$\mathrm{X}_{2}$ is the proportion of particles size below silt $(\mathrm{GS}<0.05 \mathrm{~mm})(\%)$

$\mathrm{X}_{3}$ is loss on ignition (LOI) of soil (\%)

According to equation (3), the STP contents of soils in study area can become higher under the conditions which are the ORP is high, grain size below silt $(\mathrm{GS}<0.05 \mathrm{~mm})$ is low, the organic matter is rich. The former studies reported that phosphorus tends to accumulate in soil with oxidation condition and high content of organic matters, where STP content is also high (Wang et al., 2007; Ann et al., 1999). Also, the larger the proportion of clay or silt in soil, the easily STP can be accumulated generally (Andrieux-Loyer \& Aminot, 2001). However, an opposite result was obtained in this study (Sec. 4.5).

Table 3. Multiple regression analysis among STP contents, $\mathrm{pH}$, ORP, grain size (GS $<0.05 \mathrm{~mm})$ and LOI

\begin{tabular}{cccc}
\hline Variable & Coefficient & Standard error & $\mathrm{P}_{\alpha}$ \\
\hline Intercept & 519.31 & 701.95 & 0.47 \\
$\mathrm{pH}$ & -90.32 & 93.83 & 0.35 \\
ORP $(\mathrm{mV})$ & 1.78 & 0.49 & 0.00 \\
GS $(<0.05 \mathrm{~mm})$ & -11.17 & 3.54 & 0.00 \\
LOI (\%) & 27.60 & 4.46 & 0.00 \\
Standard deviation & 218.5 & 272.8 & 0.2 \\
\hline
\end{tabular}

In addition, as phosphorus can be adsorbed by soil easily, it is believed that STP contents in soils and TDP concentrations in water have good positive correlation. However, the same characteristics can not been found between the STP contents of soils and the TDP concentrations of groundwater and spring water, suggested the movement of phosphorus in the study catchment.

\subsection{Adsorption Characteristics of Phosphorus in Soil}

According to TDP concentrations of groundwater and spring water, the soil samples at sites of right side (S4), center (R2) and left side (S16) in different depth ( $2 \mathrm{~m}, 1 \mathrm{~m}$ and surface) in the wetland where the TDP concentrations exceed the environmental standard $(0.020 \mathrm{mg} / \mathrm{L})$ were selected to estimate the adsorption characteristics of phosphorus based on the adsorption experiment.

Based on results of the adsorption experiment, the adsorption isotherm has been drawn (Fig. 8). The adsorption isotherm illustrates relation between solute equilibrium concentration $\left(\mathrm{C}_{\mathrm{eq}}\right)$ and amount of solid adsorption $(\mathrm{Q})$. In this study, the Langmuir formula was selected for the fitting adsorption isotherm. When initial concentration phosphorus in solution is low or medium, Langmuir formula can be changed as following equation ( $\mathrm{An} \& \mathrm{Li}$, 2009).

$$
\mathrm{Q}=\mathrm{M} \times \mathrm{C}_{\mathrm{eq}}-\omega_{\mathrm{NAP}}
$$

Where, $\mathrm{Q}$ is amount of phosphorus adsorption in soil $(\mathrm{mg} / \mathrm{kg})$

$\mathrm{M}$ is the adsorption constant $(\mathrm{L} / \mathrm{kg})$

$\mathrm{C}_{\mathrm{eq}}$ is phosphorus equilibrium concentration in water $(\mathrm{mg} / \mathrm{L})$

$\omega_{\mathrm{NAP}}$ is leaching amount of phosphorus in soil when phosphorus concentration in water is zero $(\mathrm{mg} / \mathrm{kg})$ 


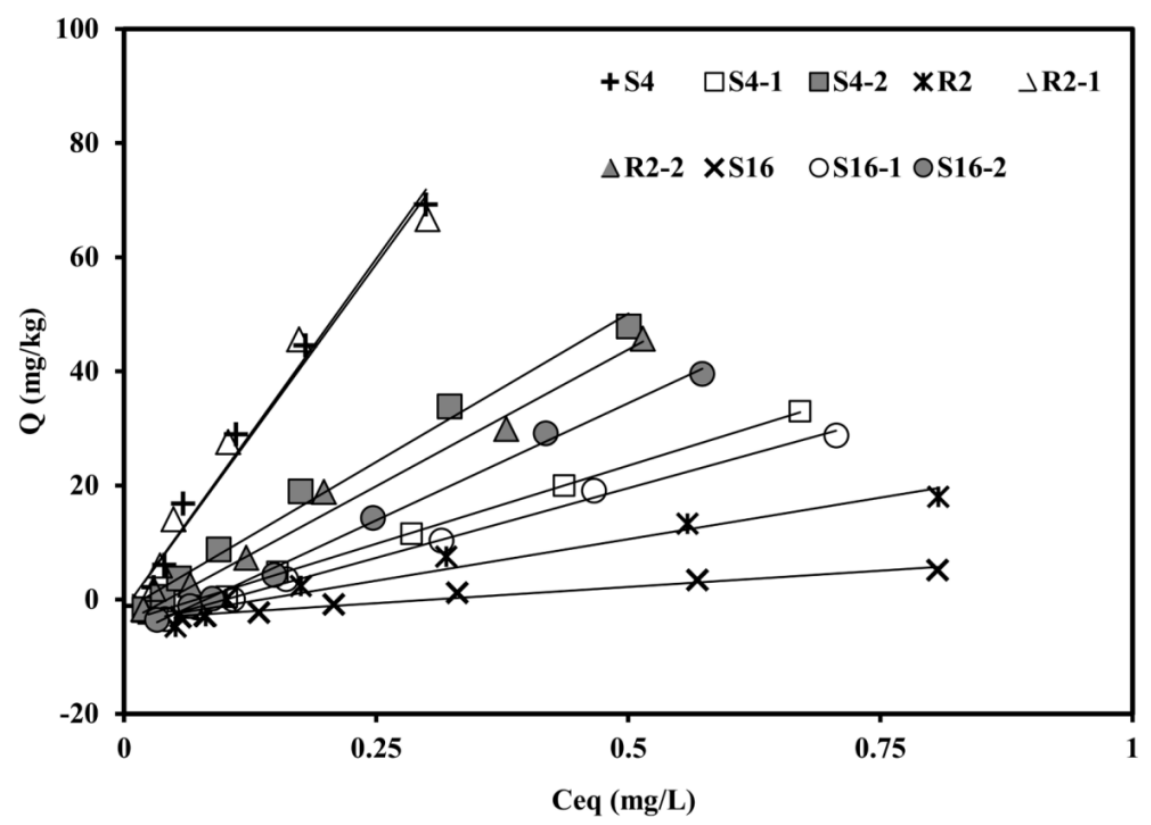

Figure 8. Phosphorus adsorption isotherm of sediments in each site

The results of application of equation (4) for different sites are shown in Fig. 8. Intersection between the isothermal line (Equation 4) and $\mathrm{C}_{\mathrm{eq}}$ axes (X-axis) is the equilibrium concentration of water when the amount of adsorption and desorption in soil for phosphorus is zero $\left(\mathrm{C}_{\mathrm{EPC}}\right)$. According to the equation (4), the $\mathrm{C}_{\mathrm{eq}}$ is $\mathrm{C}_{\mathrm{EPC}}$ when $\mathrm{Q}=0$. The data of $\mathrm{R}^{2}, \mathrm{~m}, \omega_{\mathrm{NAP}}$ and $\mathrm{C}_{\mathrm{EPC}}$ in soils are shown in Table 4.

Table 4. Values of $\mathrm{R}^{2}, \mathrm{M}, \omega_{\mathrm{NAP}}, \mathrm{C}_{\mathrm{EPC}}$ fitting of the Langmuir adsorption isotherm and TDP concentrations, state (adsorption/desorption) of phosphorus in soils

\begin{tabular}{ccccccc}
\hline Site & $\mathrm{R}^{2}$ & $\mathrm{M}(\mathrm{L} / \mathrm{kg})$ & $\omega_{\mathrm{NAP}}(\mathrm{mg} / \mathrm{kg})$ & $\mathrm{C}_{\mathrm{EPC}}(\mathrm{mg} / \mathrm{L})$ & $\mathrm{TDP}(\mathrm{mg} / \mathrm{L})$ & status \\
\hline $\mathrm{R} 2$ & 0.96 & 29 & 4 & 0.138 & 0.048 & Desorption \\
$\mathrm{S} 4$ & 0.99 & 246 & 2 & 0.008 & 0.004 & Desorption \\
$\mathrm{S} 16$ & 0.98 & 11 & 4 & 0.364 & 0.059 & Desorption \\
$\mathrm{R} 2-1$ & 0.97 & 242 & 2 & 0.008 & L.L.Q. & Desorption \\
$\mathrm{S} 4-1$ & 1.00 & 55 & 4 & 0.073 & 0.026 & Desorption \\
$\mathrm{S} 16-1$ & 1.00 & 49 & 5 & 0.102 & 0.054 & Desorption \\
$\mathrm{R} 2-2$ & 0.99 & 96 & 4 & 0.042 & 0.072 & Desorption \\
S4-2 & 0.99 & 104 & 2 & 0.019 & 0.018 & Desorption \\
S16-2 & 1.00 & 82 & 7 & 0.085 & 0.054 & Desorption \\
Standard deviation & 0.0 & 81.2 & 1.5 & 0.1 & 0.0 & $/$ \\
\hline
\end{tabular}

The $\mathrm{M}$ in equation (4) is phosphorus adsorption efficiency of soil particles, and the value of $\mathrm{M}$ is increasing with the phosphorus adsorption efficiency of soil particles (An \& Li, 2009). Generally, phosphorus will be desorbed from soil when no phosphorus in water. The desorption amount (when $\mathrm{Q}$ is negative) can be estimated based on equation (4), i.e. when " $\mathrm{C}_{\mathrm{eq}}=0$ ", " $\mathrm{Q}=-\omega_{\mathrm{NAP}}$ ". Therefore, the existing phosphorus in soil can be released when $\mathrm{C}_{\mathrm{eq}}$ is 0 . The releasable phosphorus is mainly adsorbed by soil particle surface, which can be released into water easily under certain conditions (An \& Li, 2009).

In this study, $\omega_{\mathrm{NAP}}$ was $2 \sim 7 \mathrm{mg} / \mathrm{kg}$, which was the content of phosphorus that could be released in water from soil at the sites where concentration of phosphorus in water was lower than the determination limiting $(0.002$ 
$\mathrm{mg} / \mathrm{L}$ ). In addition, the values of $\mathrm{M}$ at different sites ranged from 11 to $246 \mathrm{~L} / \mathrm{kg}$, and TDP concentrations were the high where $\mathrm{M}$ value was small.

$\mathrm{C}_{\mathrm{EPC}}$ is phosphorus equilibrium concentration in water where is no phosphorus adsorption/desorption $(\mathrm{Q}=0$, $\mathrm{C}_{\mathrm{EPC}}=\omega_{\mathrm{NAP}} / \mathrm{M}$ ). The status (adsorption/desorption) of phosphorus in soil can be estimated by comparing phosphorus concentration in water and $\mathrm{C}_{\mathrm{EPC}}$ at the same site (An \& $\left.\mathrm{Li}, 2009\right)$. Because the TP concentrations in the groundwater and spring water was almost TDP concentrations in this study (Sec. 4.3), the comparison of TDP concentration $\left(\mathrm{C}_{\mathrm{TDP}}\right)$ and $\mathrm{C}_{\mathrm{EPC}}$ should be used to estimate the status of phosphorus in soil. The estimating rules are 1) when $\mathrm{C}_{\mathrm{TDP}}<\mathrm{C}_{\mathrm{EPC}}$, phosphorus can be desorbed from soil particles, 2) when $\mathrm{C}_{\mathrm{TDP}}>\mathrm{C}_{\mathrm{EPC}}$, TDP in water can be adsorbed by soil particles, 3) when $\mathrm{C}_{\mathrm{TDP}}=\mathrm{C}_{\mathrm{EPC}}$, there is no adsorption/desorption of phosphorus in water by soil particles (balanced status)(An \& Li, 2009; Gang, 2003; Zhou et al., 2005).

As shown in Table 4, $\mathrm{C}_{\mathrm{EPC}}$ varied from 0.008 to $0.364 \mathrm{mg} / \mathrm{L}$ in study area. $\mathrm{C}_{\mathrm{EPC}}(<0.020 \mathrm{mg} / \mathrm{L})$ was relatively low at sites with low TDP concentration $(<0.020 \mathrm{mg} / \mathrm{L})$; and $\mathrm{C}_{\mathrm{EPC}}(>0.020 \mathrm{mg} / \mathrm{L})$ was relatively high at sites with high TDP concentration $(>0.020 \mathrm{mg} / \mathrm{L})$. Of samples from 9 sites where adsorption experiments had been conducted, $\mathrm{C}_{\mathrm{TDP}}$ was lower than $\mathrm{C}_{\mathrm{EPC}}$, indicating that the soils at these sites were on the status of phosphorus desorption.

At the depth of $2 \mathrm{~m}, 1 \mathrm{~m}$ and the surface wetland, the average value of $\mathrm{C}_{\mathrm{EPC}}$ was $0.049 \mathrm{mg} / \mathrm{L}, 0.061 \mathrm{mg} / \mathrm{L}$ and $0.170 \mathrm{mg} / \mathrm{L}$ respectively. $\mathrm{C}_{\mathrm{EPC}}$ tended to be higher with the depth decreasing. As a whole, $\mathrm{C}_{\mathrm{TDP}}$ was lower than the average value of $\mathrm{C}_{\mathrm{EPC}}$ at the same depth of all sites, suggested that the soil in wetland was on the status of desorption on the whole. Therefore, it can be concluded that TDP moved along with the groundwater flow without soil adsorbing, and discharged to the surface water.

Therefore, phosphorus from external resource is continually supplied to the wetland, indicating that phosphorus in the wetland soil is also continually dissolution into waters. When $\mathrm{C}_{\mathrm{EPC}}$ was high, $\mathrm{M}$ was small, the $\mathrm{C}_{\mathrm{EPC}}$ was higher than $\mathrm{C}_{\mathrm{TDP}}$ where was no phosphorus adsorbed in soil, which result in the high concentrations of TDP in groundwater and spring water $(>0.020 \mathrm{mg} / \mathrm{L})$.

The inverse correlation between STP content and particles size below silt (GS $<0.05 \mathrm{~mm}$ ) is due to the adsorption state of phosphorus in soil (formula 3 ). In general, the phosphorus adsorption capacity of clay or silt particles is better than that of sand (Del Bubba et al., 2003; Andrieux-Loyer \& Aminot, 2001). In the adsorption of phosphorus by soil, fine particles can adsorb more phosphorus. Particles smaller than silt which accumulated large amounts of phosphorus control the release of phosphorus from soil. Therefore, the more the particles below silt, the less the STP contents in soils. Because the soils in the wetland were under the dephosphorization state, STP contents and fine particles in soils were in inverse proportion.

\subsection{Phosphorus Distribution in River Water and River Sediment}

TP, TDP and TPP concentrations of waters and STP contents of river sediments from upstream to downstream are shown in Fig. 9. Concentrations of TP, TDP and TPP in well water (W1) were $0.135 \mathrm{mg} / \mathrm{L}, 0.128 \mathrm{mg} / \mathrm{L}$ and $0.007 \mathrm{mg} / \mathrm{L}$ respectively, and concentrations of TP and TDP exceed approximate 60 times than the environmental standard $(0.020 \mathrm{mg} / \mathrm{L})$. TPP concentrations of river water recharged by groundwater and spring water were also very low ranging from 0.012 to $0.048 \mathrm{mg} / \mathrm{L}$, exceeding the environmental standard $(0.020 \mathrm{mg} / \mathrm{L})$ from R1 to R3. It was obvious that concentrations of TPP in river water gradually decreased from upstream to downstream. TDP concentrations of the river in the wetland were also decreasing from upstream to downstream due to the dilution of groundwater and spring water (TDP concentrations of groundwater and spring water were lower than that of water from W1) inflow. 


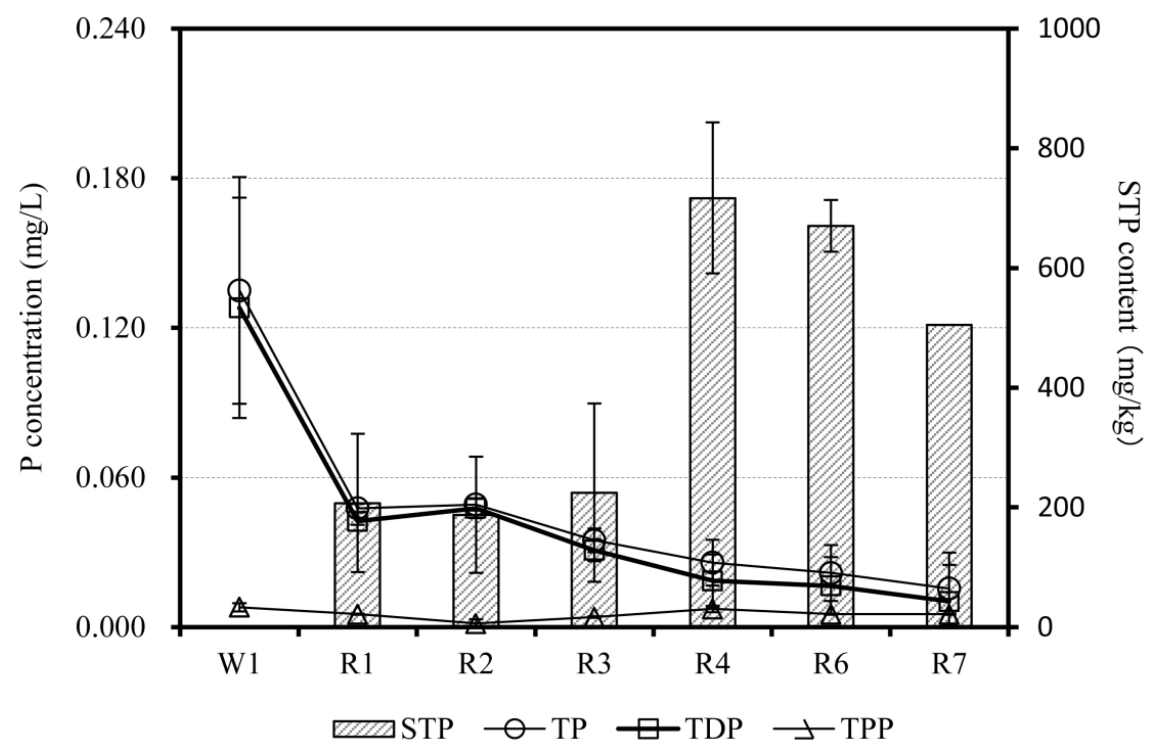

Figure 9. Variations of TP, TDP, TPP concentrations and STP contents along the river

STP contents of the river sediments were from 188 to $717 \mathrm{mg} / \mathrm{kg}$ and had a tendency to increase along the river flow direction (Fig. 9). As shown in fig. 10, As shown in Figure 10, TDP concentrations had a negative correlation with STP contents $\left(\mathrm{R}^{2}=0.70\right)$. However, there was a positive correlation $\left(\mathrm{R}^{2}=0.80\right)$ between TDP and flow velocity of river water. There was a long time contact between river water and river sediment in low velocity river. Therefore, it is considered that TDP was adsorbed by river sediment where the STP contents increased accordingly.

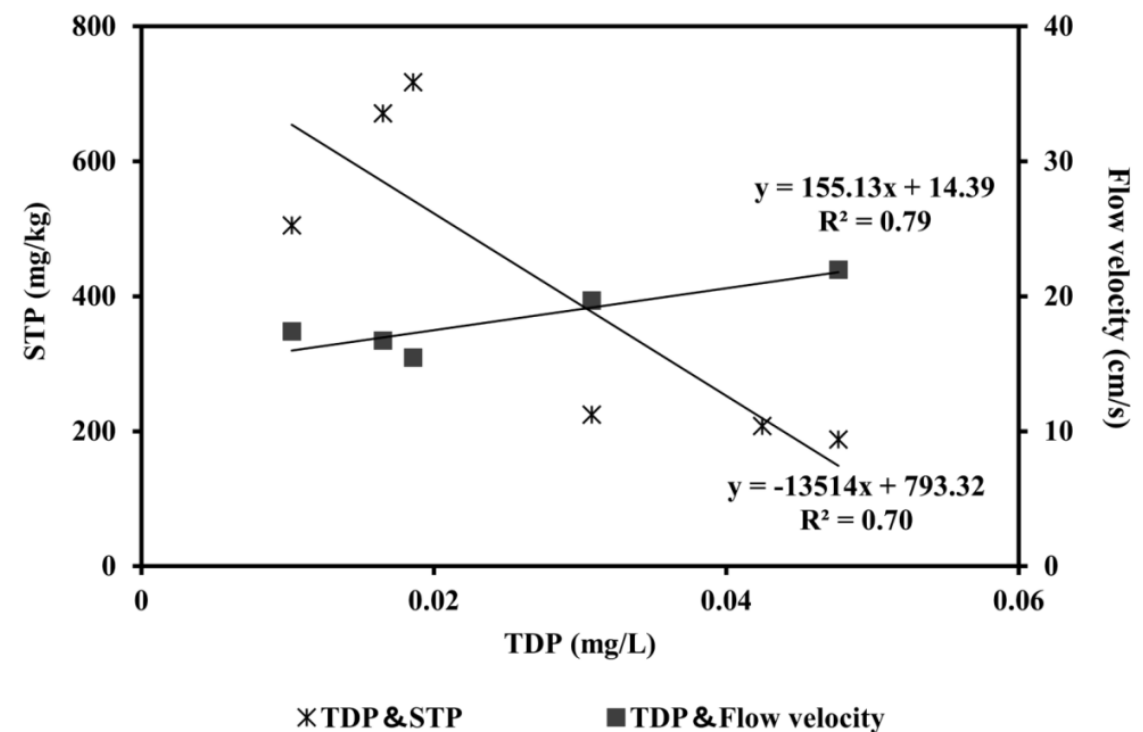

Figure 10. Correlations of STP with both TDP and flow velocity of the river

In order to evaluate the phosphorus fluxes of groundwater and spring water flow out of the wetland along with the river, TDP daily load $\left(\mathrm{F}_{\mathrm{p}}, \mathrm{g} /\right.$ day $)$ of $\mathrm{W} 1$ and the river on different section have been estimated using equation (5).

$$
\mathrm{F}_{\mathrm{p}}=\mathrm{C}_{\mathrm{TDP}} \times \mathrm{Q}_{\mathrm{x}} \times \mathrm{D}
$$

Where, $\mathrm{C}_{\mathrm{TDP}}$ is TDP concentration in water $(\mathrm{mg} / \mathrm{L})$

$\mathrm{Q}_{\mathrm{x}}$ is flow velocity $(\mathrm{L} / \mathrm{s})$

$\mathrm{D}$ is unit conversion value 86.4 
As shown in table 5, along the river flow velocity, $F_{p}$ was $21.3 \mathrm{~g} /$ day at $\mathrm{R} 1$ and $36.7 \mathrm{~g} /$ day at $\mathrm{R} 2$ which was the maximum value of the river. It is considered that phosphorus in the groundwater and spring water flow in the river from R1 to R2. Because river sediment at R2 was under dephosphorization condition (Table 4), it is considered that $F_{p}$ was increased at R2. However, $F_{p}$ gradually decreased between R2 and R7. Because the fine grain sizes of river sediment increased from upstream to downstream, the adsorption amount of phosphorus by river sediments increased theoretically. Therefore, it is indicated that the adsorption amount of phosphorus by river sediments were higher than the flux of phosphorus inflowing with groundwater and spring water. On the other hand, $F_{p}$ on site of R7 was also 20.9 g/day due to superfluous phosphorus that could not be adsorbed by river sediment. Therefore, superfluous phosphorus continuously flowed out of the catchment.

Table 5. Concentration of TDP, water flow, and TDP load of groundwater (W1) and river water at 6 sampling sites

\begin{tabular}{cccc}
\hline Site & $\mathrm{C}_{\mathrm{TDP}}(\mathrm{mg} / \mathrm{L})$ & $\mathrm{Q}_{\mathrm{x}}(\mathrm{L} / \mathrm{s})$ & $\mathrm{F}_{\mathrm{p}}(\mathrm{g} /$ day $)$ \\
\hline $\mathrm{W} 1$ & 0.128 & 1.9 & 21.0 \\
$\mathrm{R} 1$ & 0.042 & 5.8 & 21.3 \\
$\mathrm{R} 2$ & 0.048 & 8.9 & 36.7 \\
R3 & 0.035 & 10.8 & 32.7 \\
R4 & 0.019 & 15.4 & 24.7 \\
R6 & 0.017 & 15.9 & 22.7 \\
R7 & 0.012 & 19.7 & 20.9 \\
Standard deviation & 0.0 & 5.8 & 5.9 \\
\hline
\end{tabular}

\section{Conclusions}

In the wetland catchment, TP in groundwater, spring water and river water was almost in the form of TDP. Of all water samples, $41 \%$ of TP and $28 \%$ of TDP was exceed the eutrophication environmental standard $(0.020 \mathrm{mg} / \mathrm{L})$. STP contents of surface soils were larger than that of soils at $1 \mathrm{~m}, 2 \mathrm{~m}$ and $3 \mathrm{~m}$ in depth.

According to the adsorption experiment, the continual external phosphorus resource and high $\mathrm{C}_{\mathrm{EPC}}$ in water result in the high $\mathrm{C}_{\mathrm{TDP}}$ in groundwater and spring water. Phosphorus could move together with the groundwater which recharged to the river in wetland, and the TDP daily load on the discharge site of river was $20.9 \mathrm{~g} / \mathrm{day}$.

Based on conclusions in this study, TDP flowing out with groundwater may result in the eutrophication of recharged waters. Therefore, the phosphorus in groundwater should be paid extreme attention to prevent the eutrophication of surface water.

\section{References}

An, W., \& Li, X. (2009). Phosphate adsorption characteristics at the sediment-water interface and phosphorus fractions in Nansi Lake, China, and its main inflow rivers. Environmental monitoring and assessment, 148(1-4), 173-184. http://dx.doi.org/10.1007/s10661-007-0149-6

Andrieux-Loyer, F., \& Aminot, A. (2001). Phosphorus forms related to sediment grain size and geochemical characteristics in French coastal areas. Estuarine, Coastal and Shelf Science, 52(5), 617-629. http://dx.doi.org/10.1006/ecss.2001.0766

Ann, Y., Reddy, K., \& Delfino, J. (1999). Influence of redox potential on phosphorus solubility in chemically amended wetland organic soils. Ecological Engineering, 14(1), 169-180. http://dx.doi.org/10.1016/S0925-8574(99)00027-0

Arias, C., Del Bubba, M., \& Brix, H. (2001). Phosphorus removal by sands for use as media in subsurface flow constructed reed beds. Water research, 35(5), 1159-1168. http://dx.doi.org/10.1016/S0043-1354(00)00368-7

Association, J. S. (2000). Test method for particle size distribution of soils. JIS A1204 JSA, Tokyo.

Baehr, M. M., \& McManus, J. (2003). The measurement of phosphorus and its spatial and temporal variability in the western arm of Lake Superior. Journal of Great Lakes Research, 29(3), 479-487. http://dx.doi.org/10.1016/S0380-1330(03)70452-3 
Baker, J., Campbell, K., Johnson, H., \& Hanway, J. (1975). Nitrate, phosphorus, and sulfate in subsurface drainage water. Journal of environmental quality, 4(3), 406-412. http://dx.doi.org/10.2134/jeq1975.00472425000400030027x

Bennett, E. M., Carpenter, S. R., \& Caraco, N. F. (2001). Human impact on erodable phosphorus and eutrophication: a global perspective increasing accumulation of phosphorus in soil threatens rivers, lakes, and coastal oceans with eutrophication. BioScience, 51(3), 227-234. http://dx.doi.org/10.1641/0006-3568

Board, O. S. (2000). Clean Coastal Waters: Understanding and Reducing the Effects of Nutrient Pollution. National Academies Press.

Burwell, R., Schuman, G., Heinemann, H., \& Spomer, R. (1977). Nitrogen and phosphorus movement from agricultural watersheds. Journal of Soil and Water Conservation (USA).

Chen, X., Wo, F., Chen, C., \& Fang, K. (2010). Seasonal changes in the concentrations of nitrogen and phosphorus in farmland drainage and groundwater of the Taihu Lake region of China. Environmental monitoring and assessment, 169(1-4), 159-168. http://dx.doi.org/ 10.1007/s10661-009-1159-3

Cole, C., Olsen, S. R., \& Scott, C. (1953). The nature of phosphate sorption by calcium carbonate. Soil Science Society of America Journal, 17(4), 352-356. http://dx.doi.org/10.2136/sssaj1953.03615995001700040013x

Davelaar, D. (1993). Ecological significance of bacterial polyphosphate metabolism in sediments. Hydrobiologia, 253(1-3), 179-192. http://dx.doi.org/10.1007/BF00050737

Del Bubba, M., Arias, C., \& Brix, H. (2003). Phosphorus adsorption maximum of sands for use as media in subsurface flow constructed reed beds as measured by the Langmuir isotherm. Water research, 37(14), 3390-3400. http://dx.doi.org/10.1016/S0043-1354(03)00231-8

Diaz, R., Nestlerode, J., \& Diaz, M. A. (2003). global perspective on the effects of eutrophication and hypoxia on aquatic biota. In: Proceedings of the 7th Annual Symposium on Fish Physiology, Toxicology and Water Quality, Estonia, 2003. pp 12-15.

Elkhatib, E., \& Hern, J. (1988). Kinetics of Phosphorus Desorption from Appalachian Soils. Soil science, 145(3), 222-229. http://dx.doi.org/10.1097/00010694-198803000-00010

Gang, P. (2003). Metastable equilibrium adsorption theory: A challenge and development to classical thermodynamic adsorption theories. Acta Scientiae Circumstantiae, 2, 2.

Groffman, P. M., Baron, J. S., Blett, T., Gold, A. J., Goodman, I., Gunderson, L. H. ... Peterson, G. D. (2006). Ecological thresholds: the key to successful environmental management or an important concept with no practical application? Ecosystems, 9(1), 1-13. http://dx.doi.org/10.1007/s10021-003-0142-z

Han, Z., Tang, C., Piao, J., Li, X., Cao, Y., Matsumaru, T., \& Zhang, C. (2014). Application of chlorofluorocarbons (CFCs) to estimate the groundwater age at a headwater wetland in Ichikawa City, Chiba Prefecture, Japan. Applied Water Science, 4(3), 291-302. http://dx.doi.org/10.1007/s13201-013-0145-7

Heathwaite, A., Griffiths, P., \& Parkinson, R. (1998). Nitrogen and phosphorus in runoff from grassland with buffer strips following application of fertilizers and manures. Soil Use and Management, 14(3), 142-148. http://dx.doi.org/10.1111/j.1475-2743.1998.tb00140.x

Hemwall, J. B. (1957). The fixation of phosphorus by soils. Advances in Agronomy, 9, 95-112.

Hiroyuki, I., Hirata, T., Matsuo, H., Tase, N., \& Nisikawa, M. (1998). pH and Chemistry of Nitrogen, Phosphate, Sulfar and Aluminum in Surface Water Near Tea Plantation (in Japanese). J-STAGE, (594), 57-63. http://dx.doi.org/ 10.2208/jscej.1998.594_57

Holman, I., Whelan, M., Howden, N., Bellamy, P., Willby, N., Rivas - Casado, M., \& McConvey, P. (2008). Phosphorus in groundwater - an overlooked contributor to eutrophication? Hydrological Processes, 22(26), 5121-5127. http://dx.doi.org/ 10.1002/hyp.7198

Jiang, X., Jin, X., Yao, Y., Li, L., \& Wu, F. (2008). Effects of biological activity, light, temperature and oxygen on phosphorus release processes at the sediment and water interface of Taihu Lake, China. Water research, 42(8), 2251-2259. http://dx.doi.org/ 10.1016/j.watres.2007.12.003

Kaiserli, A., Voutsa, D., \& Samara, C. (2002). Phosphorus fractionation in lake sediments-Lakes Volvi and Koronia, N. Greece. Chemosphere, 46(8), 1147-1155. http://dx.doi.org/10.1016/S0045-6535(01)00242-9

Kang, W.-J., Kolasa, K., \& Rials, M. (2005). Groundwater inflow and associated transport of phosphorus to a 
hypereutrophic lake. Environmental Geology, 47(4), 565-575. http://dx.doi.org/10.1007/s00254-004-1180-3

Kunimatsu, T., Rong, L., Sudo, M., \& Takeda, I. (1994). Runoff loadings of materials causing water pollution from a paddy field during a non-planting period. Transactions of the Japanese Society of Irrigation, Drainage and Reclamation Engineering (Japan). http://dx.doi.org/ 10.11408/jsidre1965.1994.170_45

Lookman, R., Freese, D., Merckx, R., Vlassak, K., \& van Riemsdijk, W. H. (1995). Long-term kinetics of phosphate release from soil. Environmental science \& technology, 29(6), 1569-1575. http://dx.doi.org/10.1021/es00006a020

Lowrance, R., Altier, L. S., Newbold, J. D., Schnabel, R. R., Groffman, P. M., Denver, J. M. ... Brinsfield, R. B. (1997). Water quality functions of riparian forest buffers in Chesapeake Bay watersheds. Environmental management, 21(5), 687-712. http://dx.doi.org/10.1007/s002679900060

Lu, Y., Gong, Z., \& Zhang, G. (2001). Phosphorus characteristics of urban soil and its relationship with P concentration in groundwater (Chinese). Chinese Journal of Applied Ecology, 12(4), 735-738.

McDowell, R., \& Sharpley, A. (2001a). Approximating phosphorus release from soils to surface runoff and subsurface drainage. Journal of environmental quality, $30(2), \quad 508-520$. http://dx.doi.org/10.2134/jeq2001.302508x

McDowell, R., \& Sharpley, A. (2001b). Phosphorus losses in subsurface flow before and after manure application to intensively farmed land. Science of the Total Environment, 278(1), 113-125. http://dx.doi.org/10.1016/S0048-9697(00)00891-3

Nishio, M. (2005). Agriculture and environmental pollution- Soil environment policy and technology of Japan and the world (in Japanese). Rural culture association Japan.

Parfitt, R. (1978). Anion adsorption by soils and soil materials. Adv Agron, 30(1).

Piao, J., Tang, C., Sako, Y., Han, Z., Cao, Y., Dun, Y., \& Zhang, C. (2013). Spatial distribution and transport of phosphorus in a hillslop profile in Ichikawa City, Chiba Prefecture, Japan (in Japanese). Japanese association of groundwater hydrology proceedings, 60-63.

Price, R. M., Swart, P. K., \& Fourqurean, J. W. (2006). Coastal groundwater discharge-an additional source of phosphorus for the oligotrophic wetlands of the Everglades. Hydrobiologia, 569(1), 23-36. http://dx.doi.org/10.1007/s10750-006-0120-5

Reddy, K., Kadlec, R., Flaig, E., \& Gale, P. (1999). Phosphorus retention in streams and wetlands: a review. Critical reviews in environmental science and technology, 29(1), 83-146. http://dx.doi.org/10.1080/10643389991259182

Sakadevan, K., \& Bavor, H. (1998). Phosphate adsorption characteristics of soils, slags and zeolite to be used as substrates in constructed wetland systems. Water research, 32(2), 393-399. http://dx.doi.org/10.1016/S0043-1354(97)00271-6

Salvia-Castellví, M., Iffly, J. F., Vander Borght, P., \& Hoffmann, L. (2005). Dissolved and particulate nutrient export from rural catchments: a case study from Luxembourg. Science of the Total Environment, 344(1), 51-65. http://dx.doi.org/10.1016/j.scitotenv.2005.02.005

Santisteban, J. I., Mediavilla, R., Lopez-Pamo, E., Dabrio, C. J., Zapata, M. B. R., García, M. J. G. ... Martínez-Alfaro, P. E. (2004). Loss on ignition: a qualitative or quantitative method for organic matter and carbonate mineral content in sediments? Journal of Paleolimnology, 32(3), 287-299. http://dx.doi.org/10.1023/B:JOPL.0000042999.30131.5b

Sharpley, A. N. (2003). Agricultural phosphorus and eutrophication. US Department of Agriculture, Agricultural Research Service.

Sharpley, A., \& Syers, J. (1979). Phosphorus inputs into a stream draining an agricultural watershed. Water, air, and soil pollution, 11(4), 417-428. http://dx.doi.org/ 0049-6979/79/0114-0417

Sharpley, A., Ahuja, L., \& Menzel, R. (1981). The release of soil phosphorus to runoff in relation to the kinetics of desorption. Journal of environmental quality, 10(3), 386-391. http://dx.doi.org/10.2134/jeq1981.00472425001000030029x

Sprague, L. A., \& Lorenz, D. L. (2009). Regional Nutrient Trends in Streams and Rivers of the United States, 1993- 2003. Environmental science \& technology, 43(10), 3430-3435. http://dx.doi.org/10.1021/es803664x

Tadashi, K., Masawa, S.-I., \& Toyota, M. (1993). Characteristics of Effluents of Nitrogen and Phosphorous in 
Paddy Fields during The Paddling and Transplanting Season. Transactions of JSIDRE, (164), 147-155, a143. http://dx.doi.org/ 10.11408/jsidre1965.1993.164_147

Vanek, V. (1993). Transport of groundwater-borne phosphorus to Lake Bysjön, South Sweden. Hydrobiologia, 251(1-3), 211-216.

Verhoeven, J. T., Arheimer, B., Yin, C., \& Hefting, M. M. (2006). Regional and global concerns over wetlands and water quality. Trends in ecology \& evolution, 21(2), 96-103. http://dx.doi.org/10.1016/j.tree.2005.11.015

Vollenweider, R. A. (1968). Scientific fundamentals of the eutrophication of lakes and flowing waters, with particular reference to nitrogen and phosphorous as factors in eutrophication.

Wang, S., Jin, X., Pang, Y., Zhao, H., \& Zhou, X. (2005). The study of the effect of pH on phosphate sorption by different trophic lake sediments. Journal of colloid and interface science, 285(2), 448-457. http://dx.doi.org/ 10.1016/j.jcis.2004.08.039

Wang, S., Jin, X., Zhao, H., Zhou, X., \& Wu, F. (2007). Effect of organic matter on the sorption of dissolved organic and inorganic phosphorus in lake sediments. Colloids and Surfaces A: Physicochemical and Engineering Aspects, 297(1), 154-162. http://dx.doi.org/ 10.1016/j.colsurfa.2006.10.040

Wang, Y., Zhang, X., \& Huang, C. (2009). Spatial variability of soil total nitrogen and soil total phosphorus under different land uses in a small watershed on the Loess Plateau, China. Geoderma, 150(1), 141-149. $\mathrm{http}: / / \mathrm{dx}$. doi.org/10.1016/j.geoderma.2009.01.021

Way, C. (2012). Standard methods for the examination of water and wastewater. Water Environment Federation, Secaucus, NJ, USA.

Yan, C., Zhang, H., Li, B., Wang, D., Zhao, Y., \& Zheng, Z. (2012). Effects of influent C/N ratios on CO 2 and $\mathrm{CH} 4$ emissions from vertical subsurface flow constructed wetlands treating synthetic municipal wastewater. Journal of hazardous materials, 203, 188-194. http://dx.doi.org/10.1016/j.jhazmat.2011.12.002

Zhang, J.-Z., \& Huang, X.-L. (2007). Relative importance of solid-phase phosphorus and iron on the sorption behavior of sediments. Environmental science \& technology, 41(8), 2789-2795. http://dx.doi.org/10.1021/es061836q

Zhou, A., Tang, H., \& Wang, D. (2005). Phosphorus adsorption on natural sediments: Modeling and effects of $\mathrm{pH}$ and sediment composition. Water research, 39(7), 1245-1254. http://dx.doi.org/10.1016/j.watres.2005.01.026

\section{Copyrights}

Copyright for this article is retained by the author(s), with first publication rights granted to the journal.

This is an open-access article distributed under the terms and conditions of the Creative Commons Attribution license (http://creativecommons.org/licenses/by/3.0/). 